RESEARCH ARTICLE

\title{
THE PROHIBITION OF SAMPIR MARRIAGE IN THE PERSPECTIVE OF MASLAHAH MURSALAH
}

\author{
Nurwakhid Agung Kurniawan \\ Postgraduate Program, Faculty of Law, Universitas Negeri Semarang, Indonesia \\ $\triangle$ nurwakhidagungkurniawan@gmail.com
}

\section{CITED AS}

Kurniawan, N.A. (2020). The Prohibition of Sampir Marriage in the Perspective of Maslahah Mursalah. Journal of Law and Legal Reform, 1(3), 493-506. DOI: https://doi.org/10.15294/jllr.vli3.36702

\begin{abstract}
Sampir marriages are marriages between men and women separated from the road, these marriages are prohibited according to the adat community of Kenteng Village, Toroh District, Grobogan Regency. This study aims to, first, describe the prohibition of "sampir" marriage from the perspective of "maslahah mursalah", second, develop knowledge in terms of Indonesian marriage law, third, provide understanding to the village community in the village regarding the "prohibition of marriage of the sampir" perspective "maslahah mursalah". This research is an empirical study, or it can also be called field research that examines the tradition of prohibiting marriage in Kenteng Village, Toroh Sub-District, Grobogan Regency. This research includes empirical research. Data collection by observation, interview, and documentation. The author uses a qualitative method of deductive thinking in analyzing this problem, namely the process of approach that departs from general truth about a phenomenon or theory and generates that truth on an event that is characterized by the same phenomenon concerned. Overview of Islamic Law on the tradition of prohibiting marriages of sampir in Kenteng Village, Toroh Sub-District, Grobogan Regency, through the Mașlahah approach, it is a mistake that the tradition contains an element of shirk because the community believes that sampir marriage will bring disaster to the perpetrators, the community always associates the disaster that befell the marriages of the sampir perpetrators. mate sampir.
\end{abstract}

Keywords: Mașlahah Mursalah; Prohibition of Sampir Marriage; Tradition 


\section{TABLE OF CONTENTS}

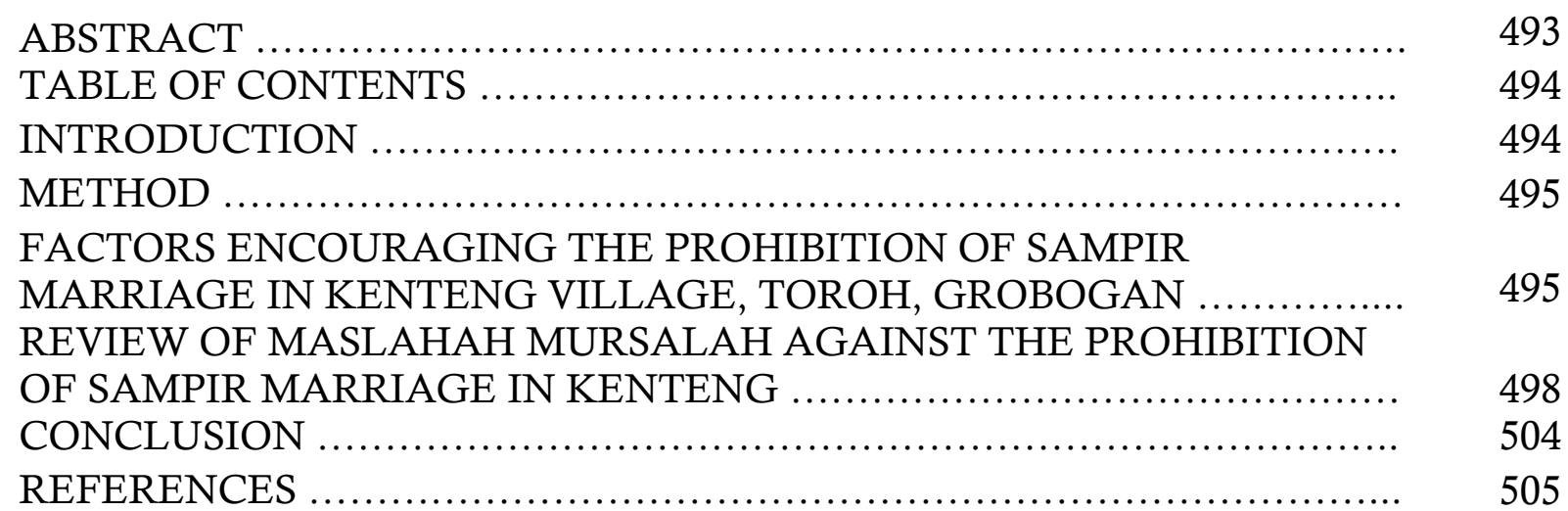

\section{INTRODUCTION}

Islam views that humans and all creatures in the universe are the creation of Allah SWT Humans are created by God complete with partners who instinctively have an interest in the opposite sex. To realize this attraction into a true relationship, one must go through marriage (Masudah 2010).

Hindu-Buddhist teachings are still embedded in Javanese culture and some people still believe in the traditions or cultural systems of traditional societies. People who break the tradition, it means leaving the existing systems. After the religion of Islam came, then the principle of their law was replaced by rules or texts based on the Qur'an and the Sunnah (Isro'i 2012).

The village of Kenteng has many traditions that are inherited from ancestors which are still preserved. For example, marital problems, many things must be met when they want to do marriage, including avoiding a marriage that has become the trust of the people of Kenteng Village. The prohibition of marriage which is still believed by the people of Kenteng Village is a ban on marriage. A marriage is a marriage between a man and a woman whose house is separated by a road in an alley. Such marriages are believed by the community to bring loggers/calamities to the perpetrators (Suhardi 2018).

The people of Kenteng Village say that tradition was inherited by the ancestors and the people still believe because there are many incidents that are not good after the marriages of the sampir (Suhardi 2018). Islam itself does not teach that Islam considers that if someone gets a disaster because something is țiyarah (predicting bad 
luck because of seeing something). The people of Kenteng Village are mostly just following the belief that the ban on marriage is based on information from parents, neighbors and closest people (Sofwan 2018).

Mujiono (2018) as a community leader in Kenteng Village revealed that there is a value to the benefit behind the prohibition of marriage in sampir in Kenteng, Toroh, Grobogan, although in Islam there is no prohibition to marry marriage. He explained that the prohibition of marrying marriage meant that it was an effort to create a harmonious and happy family. Based on the phenomenon and the reality of the tradition of prohibiting marriage in Kenteng, the author is interested in conducting research on the belief in marriage ban with the title "the prohibition of sampir marriage in the perspective of maslahah mursalah.

\section{METHOD}

This research is an empirical study, or it can also be called field research that examines the tradition of prohibiting marriage in Kenteng Village, Toroh District, Grobogan Regency. In this study, the main data source used is information from the source (primary data), supplemented by secondary and tertiary data. Data collection was carried out in three ways, namely observation, interviews and documentation. The author uses qualitative methods with deductive thinking in analyzing this problem, which is the process of approach that departs from general truth about a phenomenon or theory and generalizes that truth on a particular event or data that is characterized by the same phenomenon concerned (Nasir 2016).

\section{FACTORS ENCOURAGING THE PROHIBITION OF SAMPIR MARRIAGE IN KENTENG VILLAGE, TOROH, GROBOGAN}

The ban on sampir marriage is a legacy from the Javanese ancestors, especially in the Kenteng Village, wherein the Kenteng Village community the prohibition of marriage is seen as a myth that can lead to something undesirable if the prohibition is violated so that it becomes a sacred myth, meaning that the marriage ban becomes a necessity in the practice of one's life or even a group in the Kenteng Village community (Sofwan 2018). 
The reason for the prohibition of marriage is in the view of the people of Kenteng Village because the marriage is analogous to two people walking who will collide, turn away (reject) which makes them unable to unite, so they do not have the courage to do marriages. If this marriage is carried out it will incur disasters and misery for the bride and groom in the ark of life (Yusuf 2019).

Regarding the impact of marriage, Suhardi said: "Usually if they get married, their household will not be harmonious, there are often problems (quarreling) that end in divorce, difficult fortune, one dies, or his parents die." According to Muhamad Sofwan as a figure Kenteng Village community, he said, "It is said of parents, due to the marriage of sampir many are not strong, meaning that if there is no ill divorce if no one will die later." Regarding this ban, Muhamad Sofwan said that he himself was the perpetrators of the marriage mate and his wife was sick to death, but he did not believe that the disaster that happened to him was a result of the marriage of the mire. Muhammad Sofwan believes that the disaster that befell him was purely the will of God (Suhardi 2018).

The author also conducts an interview with " $\mathrm{T}$ " as the perpetrator of the marriage mate. The author asks "I'm sorry, if I may know what calamity has happened to you since you married a marriage? He answered, "Divorced". Previously the author asked "Do you" $\mathrm{T}$ "believe that people who do marriages on the side will get a disaster? he answered, "Yes, believe". Mr "T" claimed to have a marital marriage because it was arranged by an older person and he did not want to fight the parents. " $\mathrm{T}$ " also claimed that before marriage he did not know about the ban. He knew the prohibition shortly after his divorce with his wife (Personal Interview, 2018).

Based on the results of the writer's interview with the people of Kenteng Village, there are at least 5 (five) sampir marriages that have been affected, but the writer can only interview 2 (two) people because the other actors do not want to be interviewed because they feel this is a disgrace, The 5 (five) people are " $\mathrm{T}$ " (divorced from his wife), Muhamad Sofwan (his wife died), "Sahli" (divorced), Harwati (Divorced), Yanto (parents died).

According to Yusuf (2018) that trusting the prohibition of marital marriage is permissible because it is an estimate/belief, but do not let these estimates be put forward to defeat his belief in God, he also stressed that the community is more committed to the Koran and Hadith as guidelines for human life. Furthermore, he explained about believing in marrying sampir, "So old-fashioned parents did not allow or forbid married marriage. But prohibiting does not mean haram, (but) prohibiting (because) culture." According to Muhammad Yusuf personally, the prohibition does not mean haram according to religion because Islam implicitly does not regulate 
prohibition of marriage to marriage, but the belief is haram in the adat community of Kenteng Village. He asserted as follows:

If there is a problem with calamity, a child who does not get married will get a disaster, and those who marry will not get a disaster. The problem of the disaster had nothing to do with mating. because the calamity is a trial, the trial is the essence from God, the trial is included in the test of life. So, the ones who marry the sampir don't get any disaster, those who don't marry the sampir get lots of disasters too. Because when a disaster happens, everyone gets a disaster, so not everyone gets a disaster. It's just that there has been a person who marries the sampir then gets a disaster, because what is known is the marriages of the sampir, not from God.

Talking about tradition or tradition is closely related to the daily life of the local community. Observing the traditions of Javanese people, that is, people who are wellknown for their traditions or hereditary habits is an effort that is closely related to the development of mental and spiritual fields to live their daily lives because the ancestors of the Javanese always decrease the natural knowledge that they obtain to their children, grandchildren and his relatives. The natural knowledge gained by these ancestors eventually transformed into customs or habits that we often encounter in our daily lives (Syaifudin 2017: 70-71).

Suhardi (2018) as the traditional leader of the Kenteng Village community said that the ban on sampir marriage in principle is an effort to create a harmonious family. Like Mr. Suhardi, Mujiono (2018) explained:

(Sampir marital trust) is indeed a hereditary belief. Family people want to create a sakinah family, mawadah wa rahmah. With married marriage done, if there is a problem (between husband and wife), parents are worried that both parties will find out, and usually, the parents sometimes intervene and defend their children and it is feared that it will cause disunity/divorce due to the marriage of the sampir. Because if a family whose house is close together, if there is a problem let alone their parents interfere with 
their affairs (husband and wife), then the problem is worried that it will even get bigger so that it carries on until the children and grandchildren and so on.

Social relationships that are built with individuals must be pleasant, peaceful, friendly and show unity and unity, in other words, the relationship must be characterized by a spirit of togetherness, harmony, harmony, calm and peace. Such relationships are like an ideal relationship of friendship or family without disputes and disputes. The spirit of life that unites in purpose while instilling a sense of caring, mutual help, and mutual cooperation. This is a communal life imbued with the spirit of the Javanese people that embodies refinement, cooperation, mutual acceptance, non-discrimination and willingness to compromise (Syaifudin 2017: 74).

Based on these data, the authors draw conclusions about the factors prohibiting sampir marriage in Kenteng Village as follows:

a) The community still believes that the marriage of sampir can bring disaster to the perpetrators.

b) The community considers that if the perpetrators of mating have a disaster, the disaster is directly linked to the act of marrying the mates.

c) there are witnesses and perpetrators of mating sampir who directly know the calamity that befell the perpetrators of mating sampir.

d) the spread of the tradition of prohibiting marital marriage is hereditary.

e) lack of public knowledge about religious knowledge, especially related to the myth of the traditional belief in prohibiting marriage.

f) The public's perception that there is a value of the benefit in the tradition of prohibiting marriage.

\section{REVIEW OF MASLAHAH MURSALAH AGAINST THE PROHIBITION OF SAMPIR MARRIAGE IN KENTENG}

Marriage is a method chosen by Allah SWT as a way for His creatures to multiply and preserve their lives. According to Law No. 1 of 1974 Marriage is an inner and outer bond between a man and a woman as husband and wife with the aim of forming a happy and eternal family (household) based on the Godhead of the Almighty (Aulia 2011: 76; Putri \& Arifin 2019; Muntamah, Latifiani, \& Arifin 2019). When viewed from 
its purpose, Marriage is an important event in the history of human life, marriage will unite men and women who previously had no ties to become a sakinah, mawadah and rahmah family (Aulia 2011; Muntamah, Latifiani, \& Arifin 2019).

In Javanese tradition marriage is a sacred event, therefore the consideration of accepting a prospective son-in-law must not be arbitrary and must be based on seeds, quality, and weight (Isro'i 2012: 21-22). Referring to some of the notes above, when the tradition of prohibiting marriage of marriage is viewed from an Islamic perspective, the authors quote the following theories and rules:

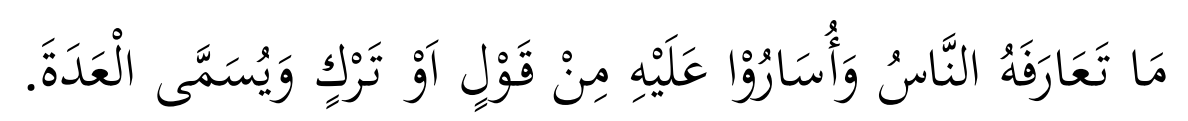

Something that has been known to humans and they make it as a tradition, both in the form of words, actions or attitudes leaving the urf is also called customs (Waid 2014: 150).

Based on the theory and rules above, it can be said that the prohibition of marriage is a custom or tradition that has benefits in it, this is indicated by several things, namely:

1) The ban on sampir marriage has been trusted, practiced, happened repeatedly, maintained by the people of Kenteng Village continuously, if the act is only done once, then the act fails to be predicated as a tradition.

2) The prohibition of marrying sampir has been known by the people of Desa Kenteng and most people practice this practice.

3) The prohibition of marriage in marriage prevents ongoing problems in social life. This is due to problems that arise in the household because the houses of both parties are very close together so that it allows the parents to interfere who tend to defend their respective children. It is feared that this problem will make it even greater until divorce arises and the problem is carried from generation to generation until the children and grandchildren so that bad relationships arise in social life.

4) The ban on sampir marriage is an effort to form a peaceful, pleasant, friendly life and show unity and unity, in other words, this prohibition is to create community relations with a spirit of togetherness, harmony, harmony, calm and peace. This is a communal life imbued with the spirit of the Javanese people that embodies refinement, cooperation, mutual acceptance, nondiscrimination and willingness to compromise. 
When viewed in terms of quality and benefit, the ban on sampir marriage is included in the Mașlahah al-ururiyyah, the meaning of mașlașah al-daruriyyah is the benefit associated with the basic needs of mankind in the world and the hereafter. The ban on sampir marriage is included in this scope because the ban on sampir marriage is in the form of provisions relating to basic human needs (principle) to carry out life and care for offspring, therefore this prohibition cannot be categorized as mașlahah alhajiyah (benefit in the form of relief to maintain and maintain basic human needs, such as cooperation in agriculture, etc.) and mașlahah al-tahsiniyyah (benefits in the form of freedom that can complement previous benefits such as eating nutritious food, dressing well, etc.) (Zahrah 2005: 424).

Maslahat in the maslahah dharuriyyah islamiyyah refers to the five preservation of maintaining religion, soul, intellect and descent, wealth (Ilyas 2014).

1. Maintaining Religion

Islamic Sharia was revealed in order to maintain the maqasyid al-khamsah / kulliyah al-khamsah. Religion is the most important level of the maqasyid, because religion is the spirit, the others are only branches. Branches will not be able to stand, except by preserving religion. There are three important points relating to the maintenance of this religion, first, that religion is fitrah, then man must have religion whether his religion is right or wrong, if he comes out of his fitrah, then there will be anomalies and deviations, but what is meant by religion here is religion correct. Second, concerning the maintenance of religious media. Preserving religion is the most important maqasyid and it is not possible that this great intention is wasted, turned around and changed, because if it is so, then other intentions are wasted. This is the same as a society that has no leader (Ilyas 2014: 18).

The maintenance of religion in its application to daruriyyah can be exemplified in the following cases: the commandment of man by Allah SWT to perform prayers and perform zakat and various other religious orders aimed at the benefit. Vice versa relating to the prevention of things that can lead to its absence, such as the order to do jihad, and the determination of the punishment for apostates, because this will be able to come to the interpretation of the existence of religion. (dar'ul mafasid) (Ilyas 2014: 18).

2. Nurturing the Soul

Islamic Sharia is very concerned with preserving the soul, then between the law stipulates it as an important benefit and rejects the things that are mafsadat, because if the life is wasted, the believer disappears, and in turn 
disappear will lead to the loss of religion, what is meant by the soul here is the soul maintained, as for other souls such as the lives of people who are fought, then he is not a soul maintained by the Shari'a, because he is an enemy of Islam (Ilyas 2014: 19).

The scholars agreed to say that the purpose of the Shari'a was revealed by Allah to preserve the human soul. They gave an example of the rules of Shari'a that were revealed by Allah with regard to this matter, namely: in the manner of killing without justified reasons of the Shari'a, the obligation of qishas to be punished accordingly, prohibited from committing suicide, may not kill children for fear of poverty and many others. All of that is in order to preserve the soul and ensure the continuity of human life and it is related to mașlahah daruriyyah (Ilyas 2014).

3. Maintain Reason

The purpose of maintaining the mind is to keep the mind from being damaged, which results in the mukallaf not having any use in society, even becoming a source of disaster. Imam Syatibi gave an example of preserving reason by prohibiting humans from drinking khamar. Because khamar can damage the mind, and in turn can damage the others, including damaging religion. It can be believed that people whose minds are broken open wide opportunities to commit crimes and damage all the strata of the benefits that exist, both dharuri, pilgrimage, tahsini, and mukammilat. For the preservation of reason from damage, it can be done by guaranteeing freedom of thought, study, and so on (Ilyas 2014).

4. Heredity / Honor

Abdul Wahhab Khallaf states that caring for offspring is a basic necessity for human benefit. Caring for offspring is a form of caring for human sustainability and fostering the mentality of generations to create a sense of friendship and unity among humans. To realize that purpose, a properly organized marriage institution is needed, as well as preventing acts that damage oneself and offspring, such as adultery and so on (Ilyas 2014).

5. Maintaining Assets

Maintenance of assets is done by preventing acts that tarnish property, such as theft, robbery and many other crimes against other assets, and must also be maintained by distributing them properly and properly for the sustainability of the assets, so humans are instructed to try and work in accordance with the power they have (Ilyas 2014). 
When viewed from the level of the order of the dharurat, the tradition of prohibiting marriages from marriage occupies the preservation of offspring ( النسل حفض), related to this matter, it needs to be seen that:

a. The people of Kenteng Village still believe that it is related to the myth of the prohibition of marriage to marriage, so it is clearly forbidden for the law to believe that there is a power other than God so that it is polytheistic (Sofwan).

b. Islam does not forbid to marry sampir but the custom of the people of Kenteng Village forbids to marry sampir, therefore it is clear that the custom is contrary to Islamic law by restricting humans to get married.

c. It is possible to believe that there is a benefit in the tradition of prohibiting marriages of sampir that is to realize a happy life, but this benefit is contrary to the main principle in maqasyid as-sharia which is to maintain religion that Islam does not forbid married marriage, so that reason must be set aside because maintaining religion must be prioritized rather than raising offspring.

d. Community beliefs about the tradition of prohibiting marriage of marriage are preserved if it is preserved so that this belief will live continuously so that there is a bad view among the people of Kenteng.

e. The people of Kenteng Village are also not allowed to associate the calamity that befell the marriages of the sampir as a result of the behavior of the sampir marriages, because everyone must experience unlimited calamity whether he is a practicing mating or not.

Based on this the authors quote the rules of fiqhiyah as follows:

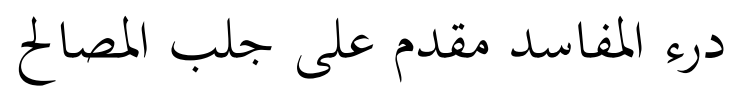

"Refusing mafsadah takes precedence over reaching Maṣlaḥah (Jazuli 2017: 29)."

Based on these rules when maslahat and mafsadat face each other, it is generally preferred to reject the mafsadat because sharia's attention to guarding the prohibition is higher than keeping the commandments. When viewed in terms of the benefits and interpretations of the tradition of prohibiting marriages of marriage, then this trust must be set aside by having to always hold fast to the Koran and the Hadith because the accident came purely because of God's will not because of the act of marrying marriage, besides believing that the perpetrators of marriage sampir will get a disaster including tiyarah and that includes something that is forbidden (Ihsan 2004: 87). 
The benefit in the tradition of prohibiting marriage of sampir is hereby ruled out because the majority of the community still believes in the tradition of prohibiting marriage of sampir with all the consequences arising and the tradition of prohibiting marriage of the sampir occupies the level of raising offspring (hif $d$ al-nasl). contrary to the principle of safeguarding religion (hif-al-din), because the concept of prohibiting marital marriage is contrary to the concept of Shari'a that already exists in Islam at the level of daruriyyah khomsah, therefore preserving religion by practicing religion in accordance with the Koran hadith statement that Islam does not forbid people to marry sampir and there is an element of shirk in the tradition, it must be prioritized rather than guarding offspring.

If the benefit referred to by some of the people of Kenteng Village in the tradition of prohibiting marital marriage is in the context of forming a harmonious family, then this is canceled because it does not meet the requirements to be categorized in the problematic problem, this is because:

1) This benefit is only a tradition in the village of Kenteng, while in other regions it is not certain to experience the same thing. Khallaf in his book said that the benefit is general, not personal. Its purpose is to prove that the formation of law in a case can bring benefits to the majority of humanity or reject danger from them and not for the benefit of individuals or some people. The law should not be prescribed to realize special benefits for the authorities or authorities and turn the attention and benefit of the majority of the people, in other words, all benefits must benefit humanity (Khallaf 2002: 144).

2) The benefit is contrary to the text. Al-Quran and as-sunnah there is not a single verse or hadith that prohibits mating marriage. Abdul Wahhab Khallaf said that the formation of law based on benefit does not conflict with laws or principles based on the text or ijma'. Therefore, it is not right to recognize benefits that demand equality between men and women in the inheritance section, because such benefits are invalid because they contradict the Qur'anic text, therefore the benefits contained in the prohibition of marriages of sampir are munasib al-mulga (which was canceled) because the syarak indicated the nullification of the confession (Khallaf 2002: 144-145). 


\section{CONCLUSION}

Based on the presentation of the results of the research and analysis of the previous chapter, the author can conclude the following:

1. Factors that encourage the prohibition of marriage in Sampeng are as follows:

a. The community still believes that the marriage of sampir can bring disaster to the perpetrators.

b. The community considers that if the perpetrators of mating have a disaster, the disaster is directly linked to the act of marrying the mates.

c. There are witnesses and perpetrators of mating sampir who directly know the calamity that befell the perpetrators of mating sampir.

d. The spread of the tradition of prohibiting marital marriage is hereditary.

e. Lack of public knowledge about religious knowledge, especially related to the myth of the traditional belief in prohibiting marriage.

f. The public's perception that there is a value of the benefit in the tradition of prohibiting marriage.

2. The review of Islamic law with the problem of the ma'lahah approach to the tradition of prohibiting marital marriage in Kenteng Village gives the view that the community must leave the tradition because it is contrary to uriaruriyyah that must be prioritized, namely yakniifd al-din in the uriaruriyyah al khamsah level. This is based on Islamic legal rule

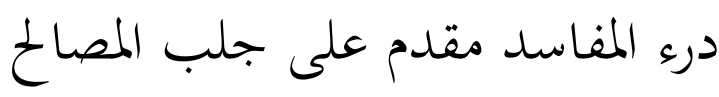

The above rule explains that rejecting mafsadah takes precedence overachieving benefit.

3. The benefits contained in the tradition of prohibiting marriages in the village of Kenteng do not meet the requirements for inclusion in the category of maslahah mursalah, but in the category of al-mulga mașlahah (which is canceled) because this benefit is the benefit of a group of people not all of humanity and this benefit contradicts by the passage of the Koran. 


\section{REFERENCES}

Aulia, A. (2011). Compilation of Islamic Law. Bandung: CV. Nuance Aulia.

Aulia, A. (2011). Law Number 1 of 1974 concerning Marriage. Bandung: CV. Nuance Aulia.

Ihsan, A.G. (2004). Rules of Islamic Law. Semarang: Sujiantoko Basscom Multimedia Grafika.

Ilyas, I. (2014). Stratification of Maqashid Al-Shari'ah Towards Goodness and Its Application. Journal of Islamic Law, 14(1), 74-86.

Isro'i, M. (2012). Prohibition of Marriage in Muharram Month in Javanese Traditional Perspective of Islamic Law (Case Study in Bangkok Village, Karanggede District, Boyolali Regency). Thesis, Salatiga: STAIN Salatiga.

Jazuli, A. (2017). The Principles of Jurisprudence: The Rules of Islamic Law in Resolving Practical Problems. Jakarta: Kencana.

Khallaf, A.W. (2002), Usulul Figh Science, trans. Noer Iskandar al-Bansany, Rules of Islamic Law. Jakarta: PT. Raja Grafindo Persada.

Masudah, R. (2010). The Phenomenon of Marriage Obstacles in the Trenggalek Indigenous Community. Law and Sharia Journal, 1(1), 33-50.

Muntamah, A.L., Latifiani, D., \& Arifin, R. (2019). Pernikahan Dini Di Indonesia: Faktor dan Peran Pemerintah (Perspektif Penegakan dan Perlindungan Hukum Bagi Anak). Widya Yuridika 2 (1), 1-12. DOI: https://doi.org/10.31328/wy.v2il.823

Nasir, K. (2016). Myth Phenomenon of Marriage Prohibitions in Jetis Village and Rogomulyo Village, Kaliwungu District, Semarang Regency in the Perspective of Islamic Law. Thesis, Salatiga: IAIN Salatiga.

Personal Interview. (2018). With "T", Perpetrators Of Mating, December 1l, 2018.

Personal Interview. (2018). Interview With Hardi, Traditional Leader Of Kenteng Village, 12 December 2018.

Personal Interview. (2018). Interview With Muhammad Mujiono, A Religious Figure In Kenteng Village, 12 December 2018.

Personal Interview. (2018). Interview With Muhammad Sofwan, Head Of Kenteng Village, 12 December 2018.

Personal Interview. (2018). Interview With Muhammad Yusuf, A Religious Figure In The Village Of Kenteng, 12 December 2019. 
Putri, M.D.S., \& Arifin, R. (2019). Pengaruh Adat dalam Hukum Keluarga terhadap Pembaruan Hukum Nasional. Volksgeist: Jurnal Ilmu Hukum dan Konstitusi 2 (1), 73 87. DOI: 10.24090/volksgeist.v2il.2491

Syaifudin, Z.A. (2017). Customary Marriage Prohibition in Urf Perspective Suro Month (Case Study of Wonorejo Village, Poncokusumo District, Malang Regency). Thesis, Malang: UIN Maulana Malik Ibrahim.

Waid, A. (2014). Collection of Usul Fiqh Rules. Yogyakarta: Ircisod.

Zahrah, M.A. (2005). Usul al-Figh, trans. Saefullah Ma'shum, et al., Usul Fiqih. Jakarta: Pustaka Firdaus. 